\title{
STUDI KADAR GIZI, SERAT DAN ANTOSIANIN TEPUNG KACANG MERAH DAN TEPUNG KECAMBAH KACANG MERAH (Phaseolus vulgaris L.)
}

Study of Nutrient, Fiber and Anthocyanin Content of Red Bean Flour and Red Bean Sprouts Flour (Phaseolus vulgaris L.)

${ }^{1}$ Ni Made Rizka Erwinda Sari, ${ }^{2}$ Ni Wayan Wisaniyasa*, ${ }^{2}$ A. A. I. Sri Wiadnyani ${ }^{1}$ Mahasiswa Program Studi Ilmu dan Teknologi Pangan, Fakultas Teknologi Pertanian, Universitas Udayana ${ }^{2}$ Dosen Program Studi Ilmu dan Teknologi Pangan, Fakultas Teknologi Pertanian, Universitas Udayana Kampus Bukit Jimbaran, Badung-Bali

\begin{abstract}
The purpose of this study was to determine of nutrient, crude fiber and anthocyanin of red bean flour and red bean sprout flour. This study was conducted using two treatments, the first treatment without germination and the others using germination for 48 hours. Each treatment was repeated three times, then it made into flour. Red bean flour and red bean sprout flour were analyzed by paired $\mathrm{T}$ test. The results showed that red bean flours had a significant difference than red bean sprouts flour on water content, ash, protein, fat, carbohydrate, crude fiber, and anthocyanin. Water content, fat, carbohydrate and anthocyanin of red bean flour higher than red bean sprouts flour, but ash content, protein, and crude fiber of red bean sprouts flour higher than red bean flour. Characteristics of red bean flour and red bean sprout flour there were water content $6.33 \%$ and $5.13 \%$, ash content $3.67 \%$ and $3.9 \%$, fat content $4.11 \%$ and $2.81 \%$, protein content $22.8 \%$ and $26.41 \%$, carbohydrate content $63.09 \%$ and $61.75 \%$, crude fiber content $3.88 \%$ and $4.17 \%$, anthocyanin $3.37 \mathrm{mg} / 100 \mathrm{~g}$ and $2.76 \mathrm{mg} / 100 \mathrm{~g}$.
\end{abstract}

Keywords: red bean, red bean sprout flour, nutrient, crude fiber, anthocyanin

\section{PENDAHULUAN}

Indonesia sebagai negara agraris memiliki beragam jenis tanaman yang dapat dimanfaatkan sebagai sumber gizi, diantaranya adalah kacang-kacangan. Kacang-kacangan merupakan bahan pangan yang termasuk famili Leguminosa atau disebut juga polongan. Kacang-kacangan banyak dikonsumsi manusia sebagai makanan sehari-hari karena merupakan sumber gizi yang baik untuk karbohidrat, serat pangan, protein, lemak, dan mineral (Lin dan Lai, 2006). Tanaman kacang-kacangan diketahui sangat baik untuk kesehatan karena dapat mencegah beberapa penyakit seperti penyakit kardiovaskular, diabetes, obesitas, dan juga kanker kolon (Guillon dan Champ, 2002).

Melihat pentingnya tanaman kacangkacangan tersebut, telah banyak dilakukan penelitian mengenai tanaman ini. Berbagai kacang-kacangan yang telah banyak dikenal antara lain kacang kedelai, kacang hijau, kacang tanah, kacang tunggak, dan kacang merah. Salah satu kacang-kacangan yang berpotensi untuk diolah dan tinggi kandungan nutrisi, serat dan antosianinnya adalah kacang merah.

Kacang merah banyak tersedia di Indonesia dan mudah diperoleh. Hal tersebut sesuai dengan data Badan Pusat Statistik (2018), produksi kacang merah di Indonesia tergolong cukup tinggi, yaitu mencapai 37.171 ton pada tahun 2016. Oleh masyarakat lokal di Indonesia umumnya, kacang merah yang biasa disebut dengan kacang buncis ini diolah menjadi sup, kue, salad dan es krim. Kacang merah mengandung zat gizi, serat kasar dan antosianin. Kandungan zat gizi kacang merah terdiri dari unsur makro dan mikro. Menurut Mahmud et.al., 2008, kandungan makronutrien dalam $100 \mathrm{~g}$ kacang merah kering diantaranya air 17,70 g; lemak $1,10 \mathrm{~g}$; protein $22,10 \mathrm{~g}$; karbohidrat $56,20 \mathrm{~g}$; serta pada serat 4,00 g. Serta kandungan antosianin dalam $100 \mathrm{~g}$ kacang merah yaitu pada cyanidin $1,2 \mathrm{mg} / 100 \mathrm{~g}$ dan pelargonidin $2,4 \mathrm{mg} / 100 \mathrm{~g}$ (Horbowicz, M. et. al., 2008). Antosianin adalah metabolit sekunder dari 
famili flavonoid, dalam jumlah besar ditemukan dalam buah-buahan dan sayursayuran (Talavera, et al., 2004). Antosianin adalah suatu kelas dari senyawa flavonoid, yang secara luas terbagi dalam polifenol tumbuhan.

Salah satu penanganan kacangkacangan untuk meningkatkan kualitas kacang-kacangan adalah perkecambahan. Perkecambahan terbukti mampu meningkatkan kandungan isoflavon, sifat fungsional, kadar serat pangan larut (soluble dietary fibre), daya cerna protein, aktivitas antioksidan pada kecambah kacang merah maupun yang ditepungkan (Wisaniyasa et al., 2016; Wisaniyasa et al., 2017). Proses perkecambahan kacang merah juga mampu meningkatkan kadar abu, kadar protein, kapasitas antioksidan dan serat pangan serta mampu menurunkan aktivitas antitripsin tepung yang dihasilkan (Wisaniyasa dan Suter, 2016) Perkecambahan telah diketahui sebagai proses yang tidak mahal dan secara umum dapat meningkatkan karakteristik fungsional dan nilai gizi dari kacangkacangan (Vanderstoep, 1981). Hal tersebut dikarenakan adanya respirasi aerobik dan metabolisme biokimia.

Pemanfaatan produk kecambah kacang merah masih terbatas sehingga pengolahan yang dapat dilakukan adalah dengan cara penepungan. Teknologi tepung dipilih karena memiliki beberapa keunggulan, yaitu penanganannya lebih mudah dalam pengolahan maupun penyimpanan dan menjamin keamanan bahan baku. Tepung kecambah kacang merah dipilih sebagai langkah awal diversifikasi produk kecambah kacang merah karena mudah diaplikasikan sebagai bahan baku dalam pembuatan berbagai macam produk olahan pangan. Dari informasi sebelumnya mengenai komposisi kimia tepung kacang merah dan tepung kecambah kacang merah, belum ada yang mengungkap tentang kandungan serat kasar dan antosianin tepung kacang merah dan tepung kecambah kacang merah. Penelitian ini bertujuan untuk mengetahui apakah terdapat perbedaan kadar gizi, serat dan antosianin antara tepung kacang merah dan tepung kecambah kacang merah.

\section{METODE PENELITIAN}

\section{Tempat dan Waktu}

Penelitian ini dilaksanakan di Laboratorium Pengolahan Pangan dan Laboratorium Analisis Pangan Fakultas Teknologi Pertanian Universitas Udayana. Waktu penelitian dilaksanakan pada bulan Mei sampai Juni 2019.

\section{Bahan dan Alat}

Bahan utama yang digunakan dalam penelitian ini adalah kacang merah segar yang baru di panen. Bahan yang digunakan untuk analisis adalah Aquades, $\mathrm{H}_{2} \mathrm{SO}_{4}, \mathrm{NaOH}$, Alkohol, HCl, Tablet Kjeldahl, Asam Borat, PP (penolphtalin), Heksan, Buffer pH 4,5 dan Buffer $\mathrm{pH} 1$.

Peralatan yang digunakan dalam penelitian ini adalah blender (Philips), shaker (eyela multi shaker), timbangan analitik (Shimadzu), mikropipet (Socorex), cawan porselin, spektrofotometer UV - Vis (Genesys 5s Uv-Vis), tabung reaksi (pyrex), pipet volume (pyrex), gelas beker (pyrex), erlenmeyer (pyrex), kertas saring kasar, kertas saring Whatman nomor 42, alumunium foil, labu ukur (pyrex), ayakan 60 mesh, desikator, spatula dan oven (memert), destilator, labu kjeldahl, soxhlet, sentifuge (Centurion Scientific), vortex (Maxi Mix II), eksikator, corong, pipet tetes, hot plate, labu takar takar.

\section{Pelaksanaan Penelitian}

\section{Pembuatan Tepung Kacang Merah}

Proses pembuatan tepung kacang merah diawali dengan sortasi kacang merah segar sebanyak $100 \mathrm{~g}$ untuk memisahkan kotoran , lalu kacang merah dicuci pada air mengalir kemudian ditiriskan, lalu dilakukan perajangan. Kemudian dikeringkan dengan menggunakan oven dengan suhu pengeringan 
$50^{\circ}$ C sampai kering. Lalu dilakukan penggilingan dan pengayakan 60 mesh. Dihasilkan tepung kacang merah.

\section{Pembuatan Kecambah Kacang Merah}

Proses pembuatan kecambah kacang merah diawali dengan sortasi kacang merah segar untuk memisahkan kotoran, lalu kacang merah dicuci pada air mengalir kemudian ditiriskan, lalu dikecambahkan dalam wadah keranjang plastik beralaskan daun pisang dan ditutupi daun pisang. Dikecambahkan selama 48 jam pada suhu kamar dan tanpa cahaya. Jumlah kacang adalah $100 \mathrm{~g}$ dengan ketebalan $1 \mathrm{~cm}$. Selanjutnya diperciki air secara merata selama 12 jam sekali dengan membuka tutup daun pisang kemudian tutup kembali setelah diperciki.

\section{Pembuatan Tepung Kecambah Kacang Merah}

Proses pembuatan tepung kecambah kacang merah diawali dengan kecambah kacang merah dicuci pada air mengalir kemudian ditiriskan, lalu dilakukan perajangan. Kemudian dikeringkan dengan menggunakan oven dengan suhu pengeringan $50^{\circ} \mathrm{C}$ sampai kering. Lalu dilakukan penggilingan dan pengayakan 60 mesh. Dihasilkan tepung kecambah kacang merah.

\section{Parameter yang Diamati}

Parameter yang diamati dalam penelitian ini meliputi kadar air dilakukan dengan metode pengeringan, kadar abu dengan metode pengabuan, kadar protein dengan metode mikro-kjeldahl, kadar lemak dengan metode soxhlet, kadar karbohidrat dengan metode carbohydrate by different (Sudarmadji et al., 1997), kadar serat dengan metode asam basa (Sudarmadji, 1984) dan kadar antosianin dengan metode $\mathrm{pH}$ Differential (Giusti et al., 2001 dalam Al-lawi et al., 2011).

\section{HASIL DAN PEMBAHASAN}

\section{Karakteristik Bahan Baku}

Pada penelitian ini diawali dengan mengamati karakteristik kacang merah dan kecambah kacang merah. Adapun hasil analisis kacang merah dan kecambah kacang merah dapat dilihat pada Tabel 1. Kadar air kacang merah yaitu 59,09\% sedangkan kecambah kacang merah yaitu $48,16 \%$. Terjadi penurunan pada kadar air kecambah kacang merah, dikarenakan selama proses perkecambahan terjadi proses hidrolisis yaitu pemecahan pada molekul $\mathrm{H}_{2} \mathrm{O}$ menjadi kation $\mathrm{H}^{+}$dan anion $\mathrm{OH}$.

Kadar abu kacang merah yaitu 1,94\% sedangkan kecambah kacang merah yaitu 2,57\%. Terjadi peningkatan setelah dikecambahkan, hal ini kemungkinan disebabkan oleh terbentuknya mineralmineral baru seperti kalsium, fosfor, kalium, besi, seng, dan natrium (Iikujenlola dan Fashakim, 2005).

Kadar lemak kacang merah yaitu 1,09\% sedangkan kecambah kacang merah yaitu $0,93 \%$. Mengalami penurunan setelah perkecambahan, dikarenakan lemak dipakai sebagai energi selama proses perkecambahan. Adanya aktivitas enzim lipase yaitu enzim lipase akan memecah lemak, menjadi gliserol dan asam lemak.

Kadar protein kacang merah yaitu $11,86 \%$ sedangkan kecambah kacang merah yaitu $13,87 \%$. Terjadi peningkatan kadar protein setelah perkecambahan, dikarenakan adanya enzim protease yang memecah protein menjadi asam amino. Penelitian oleh Bahri, et. al, (2012) mengatakan bahwa enzim protease akan mencapai puncak aktivitasnya mendegradasi protein pada perkecambahan 26-54 jam, maka pada perkecambahan kacang merah terjadi peningkatan asam amino.

Kadar karbohidrat kacang merah yaitu 26,02\% sedangkan kecambah kacang merah yaitu $34,47 \%$. Terjadi peningkatan kadar 
karbohidrat setelah dikecambahkan, berlangsung terjadi proses sintesis struktural karbohidrat yaitu terbentuknya selulosa dan hemiselulosa yang merupakan komponen terbesar dinding sel (Syeh, 2011).

Kadar serat kasar kacang merah yaitu 6,23\% sedangkan kecambah kacang merah yaitu $8,46 \%$. Terjadi peningkatan kadar serat kasar setelah perkecambahan, dikarenakan terbentuknya selulosa dan hemiselulosa baru. Penelitian oleh Syeh, (2011) menyebutkan bahwa adanya proses sintesis struktural karbohidrat yaitu terbentuknya selulosa dan hemiselulosa yang merupakan komponen terbesar dinding sel (Syeh, 2011). dikarenakan pada saat perkecambahan Kadar antosianin kacang merah yaitu 7,21 mg/100g sedangkan kecambah kacang merah yaitu 5,31 mg/100g. Selama proses perkecambahan, ada proses pemercikan air setiap 12 jam. Air akan terserap ke dalam biji kacang merah yang mengandung antosianin. Penyerapan air akan mengaktifkan enzim yang tersimpan dan menstimulasi pertumbuhan. Antosianin memiliki sifat hidrofilik yaitu mudah larut dalam air. Enzim menghidrolisis sebagaian zat cadangan menjadi energi dan menurunkan senyawa larut yang digunakan dalam memproduksi sel jaringan (Pessarakli, 2001)

Tabel 1. Hasil Analisis Kadar Gizi, Serat dan Antosianin Kacang Merah dan Kecambah Kacang Merah.

\begin{tabular}{lcc}
\hline \multicolumn{1}{c}{ Parameter } & Kacang Merah & Kecambah Kacang Merah \\
\hline Kadar Air (\%) & $59,09 \pm 0,08$ & $48,16 \pm 0,2$ \\
Kadar Abu (\%) & $1,94 \pm 0,07$ & $2,57 \pm 0,03$ \\
Kadar Lemak (\%) & $1,09 \pm 0,19$ & $0,93 \pm 0,08$ \\
Kadar Protein (\%) & $11,86 \pm 0,42$ & $13,87 \pm 0,27$ \\
Kadar Karbohidrat (\%) & $26,02 \pm 0,64$ & $34,47 \pm 0,39$ \\
Kadar Serat Kasar (\%) & $6,23 \pm 0,22$ & $8,46 \pm 0,2$ \\
Kadar Antosianin (mg/100g) & $7,21 \pm 0,11$ & $5,31 \pm 0,12$ \\
\hline
\end{tabular}

Keterangan $n=3$

\section{Kadar Gizi, Serat dan Antosianin Tepung Kacang Merah dan Tepung kecambah Kacang Merah}

Hasil analisis kadar gizi, serat, dan antosianin tepung kacang merah dan tepung kecambah kacang merah dapat dilihat pada Tabel 2.

\section{Kadar Air}

Hasil Hasil analisis pada uji beda T test menunjukkan bahwa terjadi perbedaan kadar air dari tepung yang dihasilkan akibat proses perkecambahan $\quad(\mathrm{P}<0,05)$. Tabel 2 menunjukkan bahwa kadar air tepung kacang merah lebih tinggi dibandingkan tepung kecambah kacang merah.

Terjadi penurunan terhadap kadar air tepung kacang merah yaitu $18,96 \%$ setelah perkecambahan disebabkan karena selama proses perkecambahan terjadi proses hidrolisis yaitu proses pemecahan senyawa kompleks menjadi suatu senyawa baru (lebih sederhana). Terjadi reaksi kimia yang memecah molekul air $\mathrm{H}_{2} \mathrm{O}$ menjadi kation $\mathrm{H}^{+}$ dan anion $\mathrm{OH}$. Proses hidrolisis tersebut melibatkan air sehingga kandungan air di dalam bahan berkurang. Hal ini didukung oleh penelitian Hazmi (2016) yang 
menyatakan bahwa perkecambahan dapat kedelai. Anita (2009) juga mengungkapkan bahwa perkecambahan dapat menurunkan kadar air tepung kecambah kacang komak. Kadar air tepung yang rendah dapat mempertahankan daya simpan tepung tersebut. Hal ini disebabkan karena tingkat menurunkan kadar air tepung kecambah kadar air yang rendah yaitu $4-8 \%$ dapat meningkatkan daya simpan suatu produk. Menurut Anon (2011), tingkat kadar air yang rendah yaitu 4-8\% memungkinkan produk olahan dapat disimpan pada suhu kamar berbulan-bulan.

Tabel 2. Hasil Analisis Kadar Gizi, Serat, dan Antosianin Tepung Kacang Merah dan Tepung Kecambah Kacang Merah

\begin{tabular}{lccc}
\hline \multicolumn{1}{c}{ Parameter } & Tepung Kacang Merah & $\begin{array}{c}\text { Tepung Kecambah } \\
\text { Kacang Merah }\end{array}$ & $\begin{array}{c}\text { Perubahan setelah } \\
\text { dikecambahkan }(\%)\end{array}$ \\
\hline Kadar Air (\%) & $6,33 \pm 0,05$ & $5,13 \pm 0,07$ & $-18,98 \%$ \\
Kadar Abu (\%) & $3,67 \pm 0,03$ & $3,9 \pm 0,01$ & $+6,27 \%$ \\
Kadar Lemak (\%) & $4,11 \pm 0,1$ & $2,81 \pm 0,1$ & $-31,63 \%$ \\
Kadar Protein (\%) & $22,80 \pm 0,09$ & $26,41 \pm 0,08$ & $+15,83 \%$ \\
Kadar Karbohidrat (\%) & $63,09 \pm 0,18$ & $61,75 \pm 0,08$ & $-2,12 \%$ \\
Kadar Serat Kasar (\%) & $3,88 \pm 0,05$ & $4,17 \pm 0,03$ & $+7,43 \%$ \\
Kadar Antosianin & $3,37 \pm 0,17$ & $2,76 \pm 0,12$ & $-18,1 \%$ \\
$($ mg/100g) & & & \\
\hline
\end{tabular}

Keterangan: - = penurunan

$$
+=\text { peningkatan }
$$

\section{Kadar Abu}

Hasil analisis pada uji beda $\mathrm{T}$ test menunjukkan bahwa terjadi perbedaan kadar abu dari tepung yang dihasilkan akibat proses perkecambahan $\quad(\mathrm{P}<0,05)$ Tabel 2 menunjukkan bahwa kadar abu antara tepung kacang merah lebih rendah dibandingkan tepung kecambah kacang merah.

Terjadi peningkatan terhadap kadar abu tepung kacang merah yaitu $6,27 \%$ setelah perkecambahan kemungkinan karena pada proses perkecambahan terbentuk mineralmineral baru yang tidak ada sebelumnya. Terbentuknya mineral-mineral tersebut menyebabkan kadar abu dari tepung meningkat. Berdasarkan hasil penelitian Iikujenlola dan Fashakim (2005) yang menemukan bahwa perkecambahan jagung, beras, dan cowpea mampu meningkatkan beberapa mineral-mineral seperti kalsium, fosfor, potasium, besi, senk dan sodium.
Kadar abu merupakan parameter untuk menunjukkan nilai kandungan mineral yang ada pada suatu produk. Semakin tinggi kadar abu berarti kandungan mineralnya semakin tinggi. Anita (2009) mengungkapkan bahwa kacang-kacangan merupakan sumber mineral yang baik.

\section{Kadar Lemak}

Hasil analisis pada uji beda $T$ test menunjukkan bahwa terjadi perbedaan kadar lemak dari tepung yang dihasilkan akibat proses perkecambahan $(\mathrm{P}<0,05)$. Tabel 2 menunjukkan bahwa kadar lemak tepung kacang merah lebih tinggi dibandingkan tepung kecambah kacang merah.

Terjadi penurunan terhadap kadar lemak tepung kacang merah yaitu 31,63\% setelah perkecambahan disebabkan karena proses perkecambahan menyebabkan terjadinya perombakan lemak yang diubah menjadi energi (Mubarak, 2005). Adanya 
penurunan kandungan lemak juga disebabkan oleh peningkatan aktivitas enzim lipase (Inyang, 2008). Lemak akan dipecah oleh enzim lipase menjadi gliserol dan asam lemak secara.

\section{Kadar Protein}

Hasil analisis pada uji beda $\mathrm{T}$ test menunjukkan bahwa terjadi perbedaan kadar protein dari tepung yang dihasilkan akibat proses perkecambahan $(\mathrm{P}<0,05)$. Tabel 2 menunjukkan bahwa kadar protein tepung kacang merah lebih rendah dibandingkan tepung kecambah kacang merah.

Terjadi peningkatan terhadap kadar protein tepung kacang merah yaitu $15,83 \%$ setelah perkecambahan. Hal ini terjadi karena selama perkecambahan terbentuk asam amino yang tidak ada sebelumnya. Terbentuknya asam amino tersebut menyebabkan kadar protein yang dihitung sebagai total $\mathrm{N}$ dalam bahan semakin meningkat (Wisaniyasa dan Suter, 2016). Penentuan kandungan protein dengan metode Kjeldahl dilakukan berdasarkan penentuan kandungan nitrogen, termasuk dengan komponen lain yang mengandung nitrogen terukur sebagai nitrogen protein (Winarno, 2004). Asam amino yang terbentuk karena proses perkecambahan pada saat analisis terukur sebagai protein karena juga mengandung nitrogen.

\section{Kadar Karbohidrat}

Hasil analisis pada uji beda $\mathrm{T}$ test menunjukkan bahwa terjadi perbedaan kadar karbohidrat dari tepung yang dihasilkan akibat proses perkecambahan $(\mathrm{P}<0,05)$. Tabel 2 menunjukkan bahwa kadar karbohidrat tepung kacang merah sebesar $63,09 \%$ dan tepung kecambah kacang merah sebesar $61,75 \%$. Terjadi penurunan terhadap kadar karbohidrat tepung kacang merah yaitu 2,12\% setelah perkecambahan dikarenakan karbohidrat tersebut digunakan sebagai sumber energi selama proses perkecambahan. Karbohidrat sebagai bahan persediaan makanan didegradasi oleh enzim $\alpha$-amilase dan $\beta$-amilase. $\alpha$-Amilase akan mendegradasi pati menjadi glukosa dan dekstrin sedangkan $\beta$ - amilase memecah pati menjadi maltosa dan dekstrin, yang akhirnya akan didegradasi lagi untuk menghasilkan energi (Anggrahini, 2007)

\section{Serat Kasar}

Hasil analisis pada uji beda $\mathrm{T}$ test menunjukkan bahwa terjadi perbedaan kadar serat kasar dari tepung yang dihasilkan akibat proses perkecambahan $(\mathrm{P}<0,05)$. Tabel 2 menunjukkan bahwa kadar serat kasar tepung kacang merah lebih rendah dibandingkan tepung kecambah kacang merah.

Terjadi peningkatan terhadap kadar serat kasar tepung kacang merah yaitu $18,1 \%$ setelah perkecambahan. Peningkatan kandungan serat pada kecambah dipengaruhi oleh sintesis struktural karbohidrat seperti selulosa dan hemiselulosa yang merupakan komponen terbesar dinding sel (Syed, 2011). Kandungan serat kasar tepung kecambah serealia dan kacang-kacangan lebih tinggi dibanding dengan serat tepung tanpa dikecambahkan. Penelitian Syed (2011) menunjukkan peningkatan kadar serat pada kecambah kacang hijau.

\section{Antosianin}

Hasil analisis pada uji beda $\mathrm{T}$ test menunjukkan bahwa terjadi perbedaan kadar antosianin dari tepung yang dihasilkan akibat proses perkecambahan $(\mathrm{P}<0,05)$. Tabel 2 menunjukkan bahwa kadar antosianin tepung kacang merah lebih tinggi dibandingkan tepung kecambah kacang merah.

Terjadi penurunan terhadap kadar antosianin tepung kacang merah yaitu $0,18 \%$ setelah perkecambahan. Hal ini kemungkinan karena larutnya antosianin dalam air selama proses perkecambahan. Selama proses perkecambahan dilakukan pemercikan air sebanyak $10 \mathrm{ml}$ per $100 \mathrm{~g}$ kacang setiap 12 jam sekali. Hal ini didukung oleh pernyataan Husna (2013) yang mengatakan bahwa 
antosianin memiliki sifat hidrofilik yakni bisa larut dalam air. Penelitian Asropah et. al., (2019) yang meneliti pengaruh lama waktu perkecambahan terhadap kadar antosianin kacang kedelai hitam juga membuktikan terjadi penurunan kadar antosianin setelah perkecambahan 48 jam.

\section{KESIMPULAN DAN SARAN}

\section{Kesimpulan}

Berdasarkan hasil penelitian dapat disimpulkan hal-hal sebagai berikut:

1. Proses perkecambahan memberikan tingkat perbedaan yang nyata terhadap karakteristik tepung yang dihasilkan. Terjadi peningkatan setelah perkecambahan dalam hal kadar abu, kadar protein dan kadar serat kasar namun terjadi penurunan setelah perkecambahan dalam hal kadar air, kadar lemak, kadar kerbohidrat, dan kadar antosianin.

2. Karakteristik tepung kacang merah dan tepung kecambah kacang merah berturutturut yaitu kadar air 6,33\% dan 5,13\%, kadar abu 3,67\% dan 3,9\%, kadar lemak $4,11 \%$ dan $2,81 \%$, kadar protein $22,8 \%$ dan $26,41 \%$, kadar karbohidrat $63,09 \%$ dan $61,75 \%$, kadar serat kasar 3,88\% dan $4,17 \%$, dan kadar antosianin 3,37 $\mathrm{mg} / 100 \mathrm{~g}$ dan $2,76 \mathrm{mg} / 100 \mathrm{~g}$.

\section{Saran}

1. Perkecambahan selama 48 jam dapat dilakukan untuk meningkatkan kualitas kacang merah.

2. Perlu dilakukan kajian lebih lanjut terkait lama perkecambahan kacang merah terhadap kandungan antosianin.

\section{DAFTAR PUSTAKA}

Anita, S. 2009. Studi sifat fisikokimia sifat fungsional karbohidrat dan aktivitas antioksidan tepung kecambah kacang komak (Lablab purpureus (L). [skripsi]. Institut Pertanian Bogor,Bogor.

Anggrahini, S. 2007. Pengaruh lama pengecambahan terhadap kandungan $\alpha$-tokoferol dan senyawa proksimat kecambah kacang hijau (Phaseolus radiatus L.). Agritech, Vol. 27, No. 4. Universitas Gadjah Mada. Yogyakarta

Anonimus.2011.Pengeringan.Availablefromht tp://repository.ipb.ac.idd/bitstream/ha ndle/12345678/26980/Pusbangtepa_H asil\%20olahan\%20tempe.pdf?squece= 1.Diakses tanggal 18 September 2019

Al-Lawi, M. U. S. 2011. Kapasitas antioksidan dan stabilitas ekstrak pigmen antosianin kulit kacang gude hitam (cajanus cajan [Linn.] Millsp.) dengan variasi pelarut. [skripsi]. Universitas Sebelas Maret, Surakarta.

Asropah S., Nurrahman, dan Wikanastri H. 2019. Pengaruh lama perkecambahan terhadap rendemen, kadar antosianin, vitamin e, dan aktivitas antioksidan kecambah kedelai hitam. Jurnal Pangan dan Gizi 9 (1): 39-52.

Badan Pusat Statistik. 2018. Produksi sayuran di indonesia. http://www.bps.go.id. Diakses pada tanggal 24 November 2019.

Guilon, F dan M. M. J. Champ. 2002. Carbohydrate fraction of legumes: Uses in human nutrition and potential for health. Br. J. Nutr., 88 Supl 2:293306.

Hazmi, K. 2016. Karakteristik fisikokimia tepung kecambah kedelai. Pangan, Vol. 25 No. 2 Agustus 2016 : 105-112.

Husna, N. E., M. Novita dan S. Rohaya. 2013. Kandungan antosianin dan aktivitas 
antioksidan ubi jalar ungu segar dan produk olahannya. Agritech 33 (3): $296-302$.

Horbowicz, M., R. Kosson, A. Grzesiuk dan H. Debski. 2018. Anthocyanins of fruits and vegetables-their occurrence, analysis and role in human nutrition. Research Institute of Vegetable Crops vol. 68, 5-22. Poland

Ikujenlola, V. A. dan J. B. Fashakin. 2005. The physico-chemical properties of a complementary diet prepared from vegetable proteins. J. of Food Agriculture \& Environment Vol.3 (3\&4): 23-26

Inyang, C. U. dan U.M. Zakari. 2008. Effect of germination and fermentation of pearl millet on proximate chemical and sensory properties of instant fura a nigerian cereal food. Pakistan Journal of Nutrition 7(1): 9-12.

Lin, P. Y. dan H. M. Lai. 2006. Bioactive compounds in legumes and their germinated products. J. Agric. Food Chem., 54:3807-3814.

Mahmud, M. K., N. A. Hermana, I. Zulfianto, R. R. Ngadiarti, B. Apriyantono, Hartati, Bernadus dan Tinexelly. 2008. Tabel komposisi pangan indonesia. PT Elex Media Komputindo. Kompas Gramedia. Jakarta.

Mubarak A. E. 2005. Nutrition compotion and antinutrional factors of mungbean (Phaseolus aureus) as affected by some home traditional processes. Journal of Food Chemistry. 89(4):489-495.

Pessarakli, M. 2001. Handbook of plant and crop physiology. Eastern Hemisphere
Distribution. Edisi ke 2. The United States of America.

Steel, C. J. dan J. H. Torrie. 1991. Prinsip dan prosedur statistika. Diterjemahkan oleh Bambang Sumantri. Gramedia. Jakarta.

Sudarmadji, S., B. Haryono dan Suhardi. 1997. Prosedur analisa untuk bahan makanan dan pertanian. Liberty. Yogyakarta.

Syed, S. A., dan A. Z. 2011. Effect of sprouting time on biochemical and nutritional qualities of mungbean varieties. Journal of Agricultural Research, 5092.

Talavera, S., Felgine, C., dan Texier, O., 2004, Bioavailability of a bilberry anthocyanin extract and its impact on plasma antioxidant capacity in rats. Facultede Pharmacie, ClemontFerrand, French. Journal of Science of Food of Agriculture.

Vanderstoep, J. 1981. Effect of germination on the nutritive value of legume. Journal of Food Technology 25: 8385.

Winarno, F. G. 1980. Enzim pangan. Pusbangtepa, Bogor.

Wisaniyasa, N. W. dan I. K. Suter. 2016. Kajian sifat fungsional dan kimia tepung kecambah kacang merah (Phaseolus vulgaris L.). Jurnal Media Ilmiah Teknologi Pangan.3 (1) : 2634.

Wisaniyasa N. W., A. Selamet, dan A. A. G. N. A. Jambe. 2017. Studi daya cerna protein, aktivitas antioksidan dan sifat fungsional tepung kecambah kacang merah (Phaseolus vulgaris L.) dalam 
rangka pengembangan pangan fungsional. Vol. 4, No. 2, Hal. 122 129. Universitas Udayana. 